\title{
Immune Response Pathways in Human Keratinocyte (HaCaT) Cells are Induced by Ultraviolet B via p38 Mitogen-activated Protein Kinase Activation
}

\author{
Yasuko Mutou, ${ }^{*}, a, b$ Mitsutoshi Tsukimoto, ${ }^{b}$ Takujiro Homma, ${ }^{b}$ and Shuji Kojima ${ }^{b}$ \\ ${ }^{a}$ Microbeam Radiation Biology Group, Japan Atomic Energy Agency, 1233 Watanuki, Takasaki, Gunma 370-1292, Japan and ${ }^{b}$ Faculty \\ of Pharmaceutical Sciences, Tokyo University of Science, 2641 Yamazaki, Noda, Chiba 278-8510, Japan
}

(Received July 9, 2010; Accepted September 7, 2010; Published online September 17, 2010)

\begin{abstract}
The effect of sunlight on the development of allergic diseases is not well understood. In this study, we show that increased production of the proinflammatory mediators interleukin (IL)-10, tumor necrosis factor (TNF)- $\alpha$, and nitric oxide (NO) induced by ultraviolet B (UVB) is mediated via the mitogen-activated protein kinase (MAPK) signaling pathway in human keratinocyte (HaCaT) cells. Cells were exposed to UVB irradiation $\left(0.1-1 \mathrm{~kJ} / \mathrm{m}^{2}\right)$ either with or without specific inhibitors of NO [carboxy-2-pheryl-4,4,5,5-tetramethylimidazoline-3-oxide-1-oxyl (PTIO)], extracellular signal-regulated kinase (ERK; U0126), c-Jun NH2-terminal kinase (JNK; SP600125), and p38 MAPK (SB203580). The levels of IL-10, TNF- $\alpha$, and NO were then measured. The NO donor $[( \pm)-N-$ [(E)-4-Ethyl-2-[(Z)-hydroxyimino]-5-nitro-3-hexene-1-yl]-3-pyridinecarboxamide (NOR4)] was used to assess the involvement of NO in cytokine production. The activation of p38 MAPK was investigated in UVB-irradiated cells treated with p38 MAPK inhibitor, SB203580. The production of IL-10, TNF- $\alpha$, and NO by HaCaT cells increased upon exposure to UVB. The NO inhibitor, carboxy-PTIO suppressed NO production induced by UVB. NOR4 increased the production of TNF- $\alpha$, but not that of IL-10. The UVB-induced production of IL-10 and TNF- $\alpha$ were significantly suppressed by the specific inhibitors U0126, SP600125, and SB203580. In conclusion, UVB induced the production of proinflammatory mediators via activation of the p38 MAPK signaling pathway, suggesting that sunlight might promote the development of allergic diseases (such as dermatitis) through an augmented inflammatory response involving the increased production of proinflammatory cytokines and NO.
\end{abstract}

Key words — ultraviolet B, interleukin-10, tumor necrosis factor- $\alpha$, nitric oxide, p38 mitogen-activated protein kinase, immune response

\section{INTRODUCTION}

High levels of solar ultraviolet (UV) irradiation can cause varying amounts of biological damage to living organisms. UV is divided into several bands of differing wavelength: UVC (> $280 \mathrm{~nm})$, UVB $(280-320 \mathrm{~nm})$, and UVA $(320-400 \mathrm{~nm})$. UV rays with a short wavelength (UVB and UVC) are absorbed by stratospheric ozone and do not usually reach the earth's surface. ${ }^{1)}$ However, the risks posed by UV irradiation have increased due to ozone depletion. Therefore, the detrimental effects of UV

*To whom correspondence should be addressed: Microbeam Radiation Biology Group, Japan Atomic Energy Agency, 1233 Watanuki, Takasaki, Gunma 370-1292, Japan. Tel.: +8127-346-9544; Fax: +81-27-346-9688; E-mail: muto.yasuko@ jaea.go.jp irradiation on living organisms may increase in the future. DNA damage caused by UV irradiation is a critical event in skin photocarcinogenesis; ${ }^{2-4)}$ the absorption of UVB predominantly results in two types of DNA photodamage-the formation of cyclobutane pyrimidine dimers and 6-4 photoproducts. ${ }^{5-7)}$ It is reported that these photoproducts induce inflammatory cytokine production and subsequent systemic immune responses in the epidermis. ${ }^{8)}$ Such changes to the "balance" of the immune system may result in the development of a number of diseases. ${ }^{9)}$

Allergies, or immediate hypersensitivity reactions, result from the immunoglobulin $\mathrm{E}$ ( $\mathrm{IgE}$ )mediated release of chemical mediators from mast cells. ${ }^{10)}$ Overexpression of serum IgE is also a characteristic feature of many allergic diseases such as 
asthma and atopic dermatitis (AD), ${ }^{11,12)}$ and the $\mathrm{T}$ helper $2\left(\mathrm{Th}_{2}\right)$-type cytokines interleukin (IL)-4, IL5, and IL-10 are known to be overproduced in allergic lesions. ${ }^{11,13)}$ These inflammatory cytokines induce the hyper-production of $\mathrm{IgE}$, resulting in the development of symptoms. ${ }^{11)}$

IL-10 is produced by $\mathrm{Th}_{2}$ cells and human skin tissue $^{14-16)}$ and contributes to the development of allergic sensitivity by regulating the expression of the cytokine, interferon (IFN)- $\gamma$ and IL-12, that suppresses IgE production. Also, tumor necrosis factor (TNF)- $\alpha$ production is closely related to nitric oxide synthase (NOS) expression in keratinocytes. ${ }^{17,18)}$

Nitric oxide (NO) is also an important factor in allergic inflammatory responses. ${ }^{19-21)}$ The serum nitrate levels of patients with $\mathrm{AD}$ are significantly increased compared with those in non-atopic patients and correlate with the disease severity; they may also be involved in the pathogenesis of vasodilation and erythema in AD skin. ${ }^{20)}$ Tsukumo et al. reported that increased production of NO induced the itch-scratch response in a mouse model of AD, which was significantly suppressed by intravenous injection of a NOS inhibitor. ${ }^{19)}$ Elevated levels of UVB-induced NOS lead to the production of NO, resulting in erythema. ${ }^{22)}$

The mitogen-activated protein kinase (MAPK) is consist of three subfamilies of proline-directed serine (Ser)/threonine (Thr) kinases identified as extracellular signal-regulated kinase (ERK), c-Jun NH2-terminal kinase (JNK), and p38 MAPK. These kinases are activated by stress stimuli, such as heat shock, cytokines, and UV, and are involved in cellular proliferation, survival, and apoptosis. UVB irradiation induces NO production via p38 MAPK activation. ${ }^{23)}$ Furthermore, it is reported that the activation of MAPK is related to, and further leads to, the expression of cytokines. ${ }^{24)}$ UVB may cause the development of allergic diseases by affecting the production of inflammatory mediators, but the underlying mechanism is not clear.

Previously, we investigated whether UVB irradiation induces skin inflammation in the AD mouse model. ${ }^{9)}$ In this model, broad-band UVB promoted the development of AD-like skin lesions, along with increased levels of serum IgE and $\mathrm{Th}_{2}$ cytokines such as IL-4, IL-5, and IL-10 (produced by spleen lymphocytes). NO and TNF- $\alpha$ production by peritoneal macrophages is also increased by UVB irradiation. ${ }^{9)}$ These results indicate that solar UVB may exacerbate AD-like skin lesions, although the mechanism underlying the subsequent systemic im- mune response is still not clear. In this study, we identified a role for UVB (280-320 nm)-induced cytokines (IL-10 and TNF- $\alpha$ ) and NO production in the immune response. To clarify the mechanisms involved, we investigated the effects of UVB on the NO-dependent production of IL-10 and TNF- $\alpha$ and on MAPK activity in cultured HaCaT cells.

\section{MATERIALS AND METHODS}

Reagents — Cytotoxicity Detection Kit was purchased from Roche Applied Science (Indianapolis, IN, U.S.A.). Anti-mouse IL-10 mAb, biotin-conjugated anti-mouse IL-10 $\mathrm{mAb}$, antimouse TNF- $\alpha$ mAb, biotin-conjugated anti-mouse TNF- $\alpha$ mAb (JES5-16E3, JES5-2A5, 1F3F3D4, $\mathrm{XT} 3 / \mathrm{XT} 22$, respectively), recombinant mouse IL-10, and recombinant mouse TNF- $\alpha$ were purchased from eBioscience (San Diego, CA, U.S.A.). U0126, SP600125, and SB203580 were purchased from Calbiochem (San Diego, CA, U.S.A.). Dulbecco's modified Eagle's medium (DMEM), carboxy-2-phenyl-4,4,5,5-tetramethylimidazoline3-oxide-1-oxyl (PTIO), S-nitroso-d, and ( \pm )$N$-[(E)-4-Ethyl-2-[(Z)-hydroxyimino]-5-nitro-3hexene-1-yl]-3-pyridinecarboxamide (NOR4) were purchased from Wako Pure Chemical Industries, Ltd. (Osaka, Japan). Rabbit anti-rat p38 MAPK antibody, phosphor-p38 MAPK [Thr180/tyrosine (Tyr) 182] antibody, and donkey horseradishperoxidase (HRP)-conjugated anti-rabbit $\mathrm{IgG}$ antibody were purchased from cell signaling technology, Inc. (Beverly, MA, U.S.A.). Fetal bovine serum (FBS) was purchased from MultiSer, Trace Scientific Ltd. (Melbourne, Australia). All reagents used in this study were of reagent grade.

Cell Cultures — Human keratinocyte $\mathrm{HaCaT}$ cells (kindly provided by Dr. Takeda) were maintained in DMEM containing 10\% FBS, 100 units/1 penicillin $\mathrm{G}$, and $100 \mathrm{mg} / \mathrm{l}$ streptomycin (DMEM culture medium) with $5 \% \mathrm{CO}_{2}$ at $37^{\circ} \mathrm{C}$. For experiment, cells were seeded on $35 \mathrm{~mm}$ dishes (Corning Inc., Corning, NY, U.S.A.) and confluent cells were incubated with DMEM culture medium for $48 \mathrm{hr}$.

UVB Irradiation — A UVB lamp (HP-30LM; Atto Co., Tokyo, Japan) with a $280-320 \mathrm{~nm}$ emission peaking at $312 \mathrm{~nm}$ was used. The UVB fluence rate was simultaneously measured and integrated using a radiometer (UVX-31; UVP, Inc., San Gabriel., CA, U.S.A.) with a $310 \mathrm{~nm}$ detector placed at the same distance from the UV source as the 
cells. The irradiance at the sample level was 6$8 \mathrm{~J} / \mathrm{m}^{2}$ per s. UVB-irradiated cells were incubated with DMEM culture medium in $5 \% \mathrm{CO}_{2}$ at $37^{\circ} \mathrm{C}$ for $6-48 \mathrm{hr}$. The supernatant was stored at $-80^{\circ} \mathrm{C}$ for quantitative analysis.

Detection of Cytotoxicity - Cytotoxicity of UVB to $\mathrm{HaCaT}$ cells were lactate dehydrogenase (LDH) activity and determined by Cytotoxicity Detection Kit. LDH present in the culture supernatant ( 24 or $48 \mathrm{hr}$ post-irradiation) due to dead and plasma membrane-damaged cells. The supernatant $(100 \mu \mathrm{l})$ was subjected to the assay and the absorbance (dual wavelength, $492 \mathrm{~nm}$, background $690 \mathrm{~nm}$ ) were measured with a spectrofluorophotometer (RF-1500; Shimadzu Co., Kyoto, Japan). The value of LDH activity is expressed as a percentage of the maximum LDH activity which can be released from the $100 \%$ dead cells with $1 \%$ Triton X-100.

NO Donor and Cytokine Treatments - $-\mathrm{HaCaT}$ cells were incubated with DMEM culture medium containing chemical NO donor NOR4 $(0.5 \mathrm{mM})$, IL-10 $(100 \mathrm{ng} / \mathrm{ml})$, or TNF- $\alpha(100 \mathrm{ng} / \mathrm{ml})$ in $5 \%$ $\mathrm{CO}_{2}$ at $37^{\circ} \mathrm{C}$ for $24 \mathrm{hr}$. The supernatant was stored at $-80^{\circ} \mathrm{C}$ for quantitative analysis.

Inhibitor Treatments — HaCaT cells were incubated for $1 \mathrm{hr}$ with DMEM culture medium containing NO inhibitor carboxy-PTIO $(0.25 \mathrm{mM})$, ERK inhibitor U0126 $(1 \mu \mathrm{M})$, JNK inhibitor SP600125 $(10 \mu \mathrm{M})$, or p38 MAPK inhibitor SB203580 $(10 \mu \mathrm{M})$ in $5 \% \mathrm{CO}_{2}$ at $37^{\circ} \mathrm{C}$. Then cells were irradiated with UVB irradiation $\left(0.25 \mathrm{~kJ} / \mathrm{m}^{2}\right)$, and incubated in $5 \% \mathrm{CO}_{2}$ at $37^{\circ} \mathrm{C}$ for $24 \mathrm{hr}$. The supernatant was stored at $-80^{\circ} \mathrm{C}$ for quantitative analysis.

Determination of NO Production - NO production was measured with a $\mathrm{NO}$ analyzer system (ENO10; Eicom Co., Kyoto, Japan). Briefly, the conditioned sample solution $(100 \mu \mathrm{l})$ were agitated for 1 min with methanol $(100 \mu l)$ and centrifuged at $15000 \mathrm{rpm}$. An aliquot $(10 \mu \mathrm{l})$ of the supernatant (methanol layer) was injected into an automated NO detector-HPLC system (ENO10), where it was mixed with Griess reagent $(1.25 \% \mathrm{HCl}$ with $5 \mathrm{~g} / \mathrm{l}$ sulfanilamide, $0.25 \mathrm{~g} / \mathrm{l} N$-naphthylethylenediamine, and $2.5 \%$ phosphoric acid) and pumped at a rate of $0.1 \mathrm{ml} / \mathrm{min}$ into a reaction coil packed with copperplated cadmium filings (NO-RED; Eicom Co.), where nitrite ions $\left(\mathrm{NO}_{2}^{-}\right.$and $\left.\mathrm{NO}_{3}^{-}\right)$reacted with the Griess reagent to form a purple azo dye. The absorbance due to the dye was measured using a flowthrough spectrophotometer (NOD-10; Eicom Co.) at $540 \mathrm{~nm}$. The flow-rate of the mobile phase (NO-
CARA; Eicom Co.) was $0.33 \mathrm{ml} / \mathrm{min}$ and the injection volume was $10 \mu$ l. Calibration curves were constructed with a standard mixture, NOCARA with $690 \mathrm{mg} / \mathrm{l}$ sodium nitrite and sodium nitrate $850 \mathrm{mg} / \mathrm{l}$ $\left(10^{-2} \mathrm{M}\right)$, and the amounts in the samples were calculated from the peak areas. Concentrations of $\mathrm{NO}$ represent the sum of $\mathrm{NO}_{2}^{-}$plus $\mathrm{NO}_{3}^{-}$.

ELISA Procedures - Production of cytokines (IL-10 and TNF- $\alpha$ ) was measured by enzymelinked immunosorbent assay (ELISA) using appropriate antibodies. Briefly, flat-bottomed 96-well Maxisorp plates were coated with purified, IL-10 or TNF- $\alpha$ mAbs overnight at $4^{\circ} \mathrm{C}$. The primary mAbs were removed, and the plates were washed 3 times with wash buffer $[0.05 \%$ Tween 20 in phosphate buffered saline (PBS)], then blocked with blocking buffer $[1 \%$ bovine serum albumin (BSA) in PBS] for $1 \mathrm{hr}$ at room temperature. The plates were washed, then $100 \mu \mathrm{l}$ aliquots of standard (recombinant mouse IL-10 or TNF- $\alpha$ ) and sample were added to each well, and the plates were incubated for $2 \mathrm{hr}$ at room temperature. The wells were washed 3 times with wash buffer, then HRPconjugated anti-mouse IgE mAb or biotin-labeled IL-10 or TNF- $\alpha$ mAb was added, and the plates were incubated for $1 \mathrm{hr}$ at room temperature. The solutions in the wells were removed and the plates were washed 5 times with wash buffer. Next, $100 \mu \mathrm{l}$ of avidin-HRP (BD Biosciences Pharmingen, San Diego, CA, U.S.A.) was added to each well, and the plates were incubated for $30 \mathrm{~min}$ at room temperature. The avidin-HRP solution was removed and the plates were washed 10 times with wash buffer. Next, $100 \mu 1$ of tetramethylbenzidine substrate solution (BD Biosciences Pharmingen) was added to each well, and the plates were kept for 10 $30 \mathrm{~min}$ in the dark at room temperature for color development. The color reaction was quenched with stop solution ( $\left.50 \mu \mathrm{l}, 2.5 \mathrm{M} \mathrm{H}_{2} \mathrm{SO}_{4}\right)$. The absorbance at $450 \mathrm{~nm}$ was measured with a spectrofluorophotometer (RF-1500; Shimadzu Co.) and the sample concentrations were determined from the absorbance with reference to a standard curve. The determination ranges were $3.9-500 \mathrm{pg} / \mathrm{ml}$ (IL-10) and $0.5-32.2 \mathrm{pg} / \mathrm{ml}$ (TNF- $\alpha$ ), and the samples were appropriately diluted to obtain concentrations within these ranges.

Western-blot Analysis — HaCaT cells were washed twice with ice-cold PBS and lysed in lysis buffer containing protease inhibitor cocktail (Sigma-Aldrich Co., St. Louis, MO, U.S.A.) for $30 \mathrm{~min}$ on ice. Samples were centrifuged (10000 g, 
$10 \mathrm{~min})$ at $4^{\circ} \mathrm{C}$, and the supernatants, determined equal amounts of protein, were boiled at $95^{\circ} \mathrm{C}$ for $10 \mathrm{~min}$ with $2 \times$ sample buffer. The supernatants were analyzed by sodium dodecyl sulfate (SDS)-polyacrylamide gel electrophoresis (PAGE) in a $10 \%$ acrylamide gel, and transferred to nitrocellulose membranes. After transfer, the membranes were blocked with $2 \%$ BSA in Tris-Buffered Saline Tween-20 (TBST, 0.1\% Tween-20, $10 \mathrm{mM}$ Tris- $\mathrm{HCl}$, and $0.1 \mathrm{M} \mathrm{NaCl}$ ) overnight. The membranes were immunoblotted with rabbit anti-rat p38 MAPK antibody or phosphor-p38 MAPK (Thr180/Tyr182) antibody, for $1 \mathrm{hr}$ at room temperature. The membranes were continuously incubated with donkey HRP-conjugated anti-rabbit IgG antibody $(1: 20000)$ for $1 \mathrm{hr}$ at room temperature. Antibody binding was detected by using emitter-coupled logic (ECL) western blotting analysis system (GE Healthcare UK Ltd., Buckinghamshire, U.K.).

Statistical Analysis — Data are expressed as mean \pm S.D. The significance of differences was evaluated by means of analysis of variance (ANOVA) as the criterion.

\section{RESULTS}

\section{Effects of UVB Irradiation on Cytotoxicity}

Figure 1 shows the effects of UVB irradiation $\left(0.1-1 \mathrm{~kJ} / \mathrm{m}^{2}\right)$ and incubation time (24 and $\left.48 \mathrm{hr}\right)$ on cytotoxicity as measured by LDH activity. The LDH activity in HaCaT cells after UVB irradiation increased in a dose-dependent manner. Twentyfour hours after UVB irradiation the LDH activity was $14.5 \pm 0.9 \%$ at $0.25 \mathrm{~kJ} / \mathrm{m}^{2}$ and $51.3 \pm 3.2 \%$ at $1 \mathrm{~kJ} / \mathrm{m}^{2}$. Forty-eight hours after a UVB dose of $1 \mathrm{~kJ} / \mathrm{m}^{2}$ (highest dose tested) the LDH activity reached $103.8 \pm 1.2 \%$.

\section{Effects of UVB Irradiation on Cytokine Produc- tion}

The effects of UVB dose $\left(0.1-1 \mathrm{~kJ} / \mathrm{m}^{2}\right)$ and incubation time $(6-48 \mathrm{hr})$ on IL-10 and TNF- $\alpha$ production by $\mathrm{HaCaT}$ cells were examined and the levels of these cytokines were measured by ELISA. IL-10 levels significantly increased to 141.6 $\pm 15.3 \mathrm{pg} / \mathrm{ml}$ at a dose of $0.25 \mathrm{~kJ} / \mathrm{m}^{2} 24 \mathrm{hr}$ postirradiation compared with $28.7 \pm 6.5 \mathrm{pg} / \mathrm{ml}$ in nonirradiated cells (Fig. 2A and 2B). TNF- $\alpha$ levels were elevated in a dose- and a time-dependent manner, reaching a plateau after $24 \mathrm{hr}$ of incubation and a dose of $0.25 \mathrm{~kJ} / \mathrm{m}^{2}$ (Fig. 2C and 2D). The

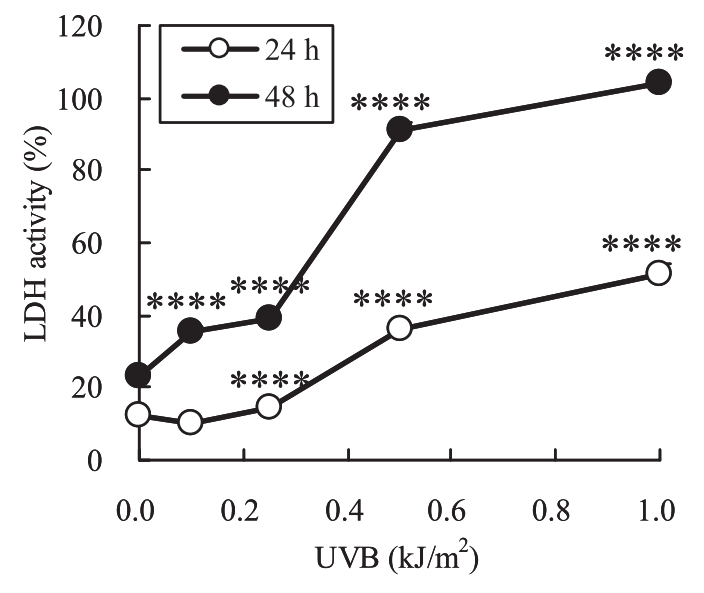

Fig. 1. Effects of UVB Irradiation on Cellular Cytotoxicity $\mathrm{HaCaT}$ cells were exposed to UVB irradiation $(0.1,0.25,0.5$, and $1 \mathrm{~kJ} / \mathrm{m}^{2}$ ) and cultured in $10 \% \mathrm{FBS} / \mathrm{DMEM}$ for $24 \mathrm{hr}$ at $37^{\circ} \mathrm{C}$ in a $\mathrm{CO}_{2}$ incubator. The value of LDH activity is expressed as a percentage of the maximum LDH activity which can be released from the $100 \%$ dead cells with $1 \%$ Triton X-100. Each value represents the mean \pm S.D. of triplicate cultures. Significant differences from the non-irradiated group are indicated: ${ }^{* * * *} p<0.001$.

maximum concentration of TNF- $\alpha$ observed was $3.7 \pm 0.7 \mathrm{pg} / \mathrm{ml}$, compared with $1.3 \pm 0.2 \mathrm{pg} / \mathrm{ml}$ in non-irradiated cells.

\section{Effects of UVB Irradiation on NO Production}

The effects of UVB dose $\left(0.1-1 \mathrm{~kJ} / \mathrm{m}^{2}\right)$ on NO production by $\mathrm{HaCaT}$ cells $24 \mathrm{hr}$ post-irradiation are shown in Fig. 3A. NO levels significantly increased after UVB irradiation in a dose-dependent manner, reaching a plateau of $6.4 \pm 2.3 \mu \mathrm{M}$ at $0.25 \mathrm{~kJ} / \mathrm{m}^{2}$. NO expression induced by a UVB dose of $0.25 \mathrm{~kJ} / \mathrm{m}^{2}$ (measured $24 \mathrm{hr}$ post-irradiation) was reduced by the addition of the NO inhibitor, carboxy-PTIO (0.25 mM, Fig. 3B).

\section{Effects of NO Donor on IL-10 and TNF- $\alpha$ Pro- duction}

$\mathrm{HaCaT}$ cells were exposed to NOR4 for $24 \mathrm{hr}$ and the levels of IL-10 and TNF- $\alpha$ were measured by ELISA (Fig. 4A and 4B). NOR4 treatment resulted in significantly increased production of TNF- $\alpha(2.7 \pm 0.1 \mathrm{pg} / \mathrm{ml})$ compared with that in non-treated cells $(1.3 \pm 0.2 \mathrm{pg} / \mathrm{ml}$, Fig. 4B). No effect on IL-10 production was observed (Fig. 4A).

\section{Effects of IL-10 and TNF- $\alpha$ on NO Production}

UVB irradiation induced increased production of IL-10, TNF- $\alpha$, and NO by HaCaT cells. To clarify involvement of these cytokines in the production of NO, either IL-10 or TNF- $\alpha$ were incubated with $\mathrm{HaCaT}$ cells for $24 \mathrm{hr}$. As shown in Fig. 5, NO lev- 

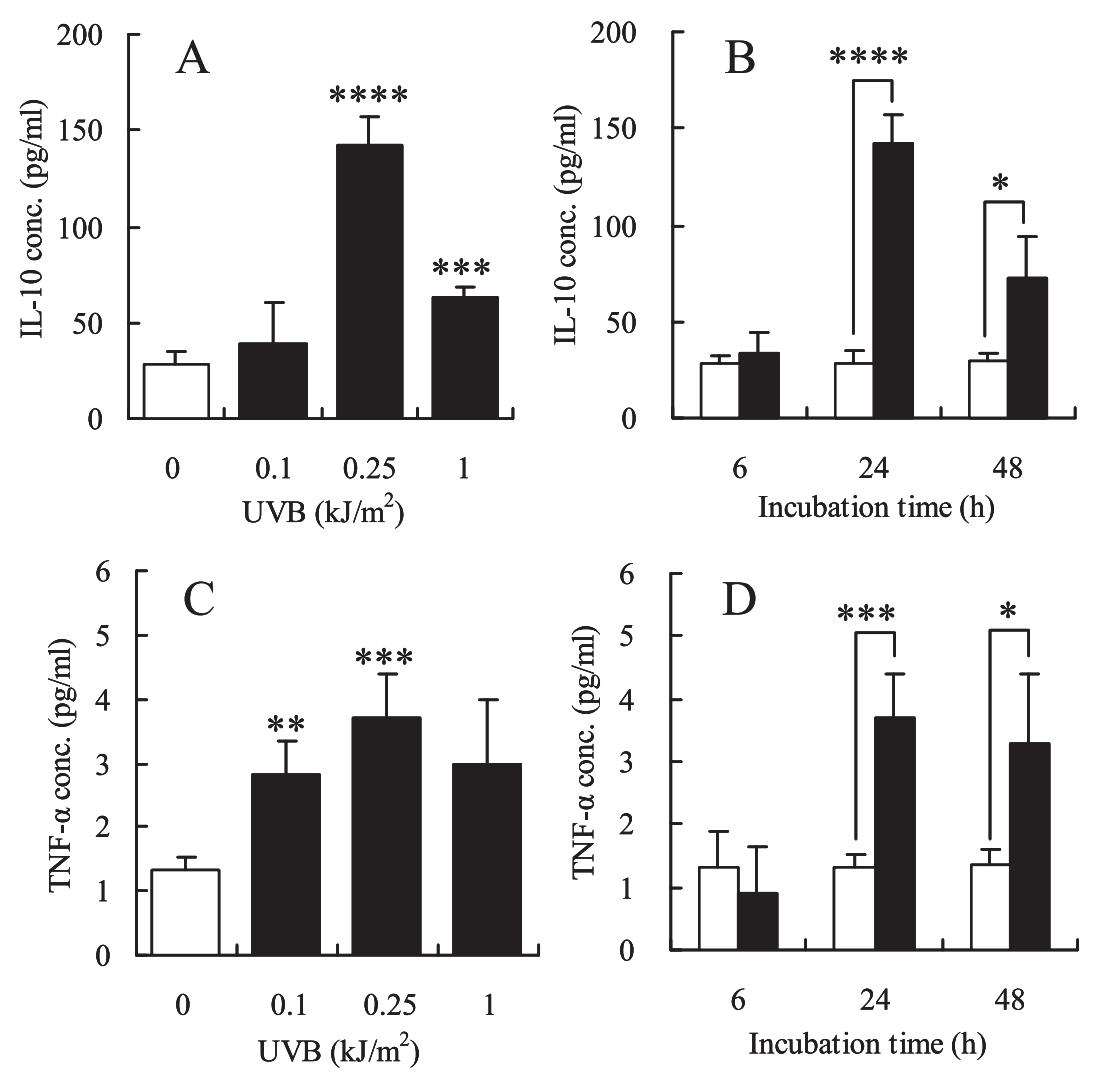

Fig. 2. Effects of UVB Irradiation IL-10 and TNF- $\alpha$ Production by HaCaT Cells

(A) Dose-dependent effects of UVB irradiation on IL-10 production by HaCaT cells. HaCaT cells were exposed to UVB irradiation $(0.1,0.25$, and $1 \mathrm{~kJ} / \mathrm{m}^{2}$ ) and cultured in $10 \% \mathrm{FBS} / \mathrm{DMEM}$ for $24 \mathrm{hr}$ at $37^{\circ} \mathrm{C}$. (B) Time-dependent effects of UVB irradiation on IL-10 production by HaCaT cells. $\mathrm{HaCaT}$ cells were exposed to UVB irradiation $\left(0.25 \mathrm{~kJ} / \mathrm{m}^{2}\right.$; black column), or not exposed (white column), and cultured in 10\% FBS/DMEM for 6, 24, and $48 \mathrm{hr}$ at $37^{\circ} \mathrm{C}$. (C) Dose-dependent effects of UVB irradiation on TNF- $\alpha$ production by HaCaT cells. HaCaT cells were exposed to UVB irradiation $\left(0.1,0.25\right.$, and $\left.1 \mathrm{~kJ} / \mathrm{m}^{2}\right)$ and cultured in $10 \% \mathrm{FBS} / \mathrm{DMEM}$ for $24 \mathrm{hr}$ at $37^{\circ} \mathrm{C}$. (D) Time-dependent effects of UVB irradiation on TNF- $\alpha$ production by $\mathrm{HaCaT}$ cells. HaCaT cells were exposed to UVB irradiation $\left(0.25 \mathrm{~kJ} / \mathrm{m}^{2}\right.$; black column), or not exposed (white column), and cultured in $10 \% \mathrm{FBS} /$ DMEM for 6, 24, and $48 \mathrm{hr}$ at $37^{\circ} \mathrm{C}$. Each value represents the mean \pm S.D. of triplicate cultures. Significant differences from the non-irradiated group are indicated: ${ }^{*} p<0.05 ;{ }^{* *} p<0.01 ;{ }^{* * *} p<0.005 ;{ }^{* * * *} p<0.001$.
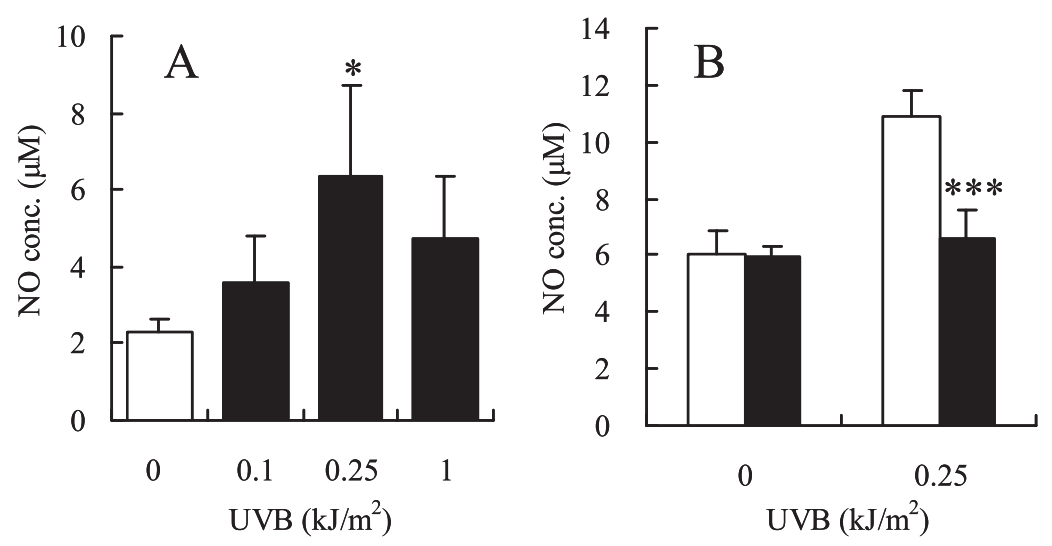

Fig. 3. Effects of UVB Irradiation on NO Production by HaCaT Cells

(A) $\mathrm{HaCaT}$ cells were exposed to UVB irradiation $\left(0.1,0.25\right.$, and $\left.1 \mathrm{~kJ} / \mathrm{m}^{2}\right)$ and cultured in $10 \% \mathrm{FBS} / \mathrm{DMEM}$ for $24 \mathrm{hr}$ at $37^{\circ} \mathrm{C}$. (B) Suppression of NO production by carboxy-PTIO. HaCaT cells were incubated for $1 \mathrm{hr}$ in 10\% FBS/DMEM containing carboxy-PTIO (0.25 mM). After UVB irradiation $\left(0.25 \mathrm{~kJ} / \mathrm{m}^{2}\right)$, cells were incubated for a further $24 \mathrm{hr}$ at $37^{\circ} \mathrm{C}$. White column $=$ non-treated; black column $=$ carboxy-PTIO. Each value represents the mean \pm S.D. of triplicate cultures. Significant differences are indicated: ${ }^{*} p<0.05 ;{ }^{* * *} p<0.005$.

els significantly increased after the addition not of TNF- $\alpha$ but of IL-10, suggesting that IL-10 had a direct effect on $\mathrm{NO}$ production.
Effects of UVB Irradiation on Cytokine Production through Activation of the p38 MAPK Signaling Pathway

To confirm whether the MAPK pathway was in- 

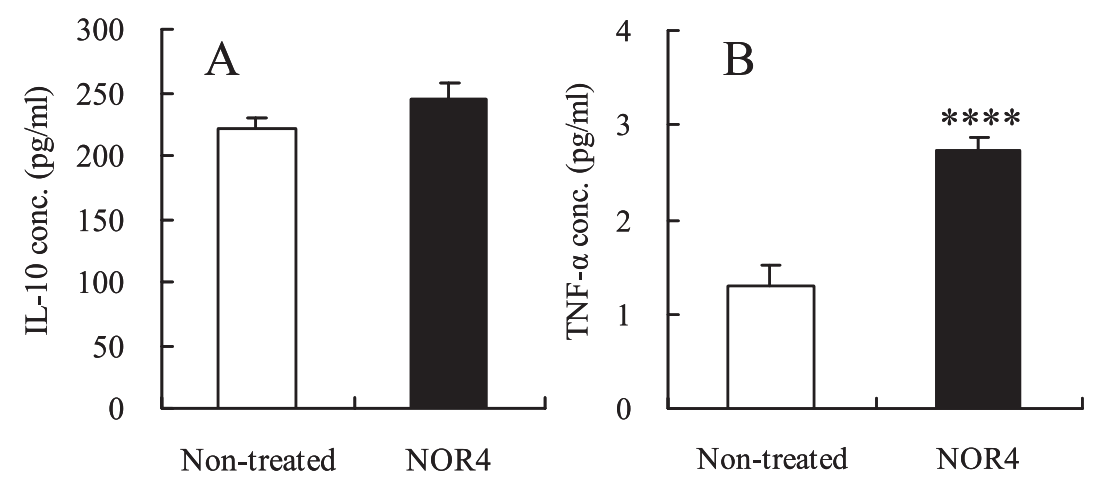

Fig. 4. Effects of NO Donor on IL-10 and TNF- $\alpha$ Production by HaCaT Cells

$\mathrm{HaCaT}$ cells were cultured with NOR4 $(0.5 \mathrm{mM})$ in $10 \% \mathrm{FBS} / \mathrm{DMEM}$ for $24 \mathrm{hr}$ at $37^{\circ} \mathrm{C}$. Each value represents the mean \pm S.D. of triplicate cultures. Significant differences from the non-irradiated group are indicated: ${ }^{* * *} p<0.001$. (A) IL-10, (B) TNF- $\alpha$.

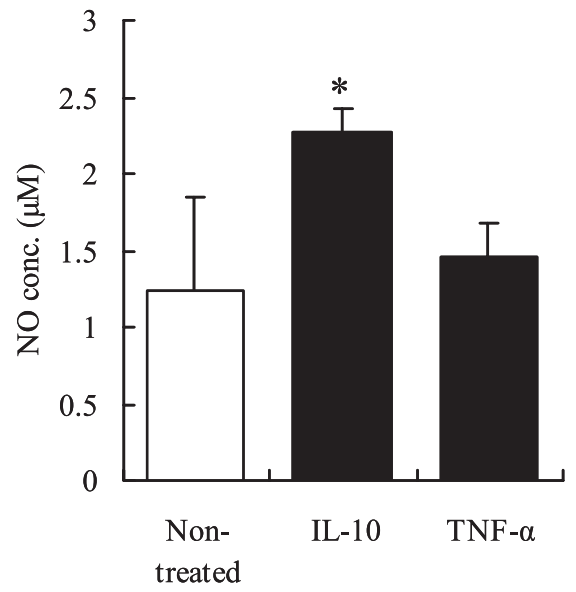

Fig. 5. Effects of IL-10 and TNF- $\alpha$ on NO Production by HaCaT Cells

$\mathrm{HaCaT}$ cells were cultured with IL-10 or TNF- $\alpha(100 \mathrm{ng} / \mathrm{ml})$ in $10 \% \mathrm{FBS} / \mathrm{DMEM}$ for $24 \mathrm{hr}$ at $37^{\circ} \mathrm{C}$. Each value represents the mean \pm S.D. of triplicate cultures. Significant differences from the non-irradiated group are indicated: ${ }^{*} p<0.05$.

volved in the UVB-induced production of IL-10 and TNF- $\alpha$, HaCaT cells were irradiated in the presence of specific MAPK inhibitors; the ERK inhibitor, U0126 $(1 \mu \mathrm{M})$, the JNK inhibitor, SP600125 $(10 \mu \mathrm{M})$, or the p38 MAPK inhibitor, SB203580 (10 $\mu \mathrm{M}$, Fig. 6). The UVB-induced production of IL-10 and TNF- $\alpha$ was suppressed by these inhibitors (Fig. 6A and 6B). We then examined the effects of UVB on the activation of p38 MAPK in HaCaT cells (Fig. 6C and 6D). As shown in Fig. $6 \mathrm{C}$, UVB treatment $\left(0.25 \mathrm{~kJ} / \mathrm{m}^{2}\right)$ caused the phosphorylation of p38 MAPK 15-360 min postirradiation (Fig. 6C). The UVB-induced activation of p38 MAPK was suppressed by the p38 MAPK inhibitor, SB203580 (Fig. 6D).

\section{DISCUSSION}

In this study, we investigated the effects of UVB irradiation on the production of proinflammatory mediators and the role of the MAPK signaling pathway in human keratinocyte (HaCaT) cells. UVBirradiated $\mathrm{HaCaT}$ cells increased production of IL10 , TNF- $\alpha$, and NO via activation of the p38 MAPK signaling pathway, suggesting that exposure to solar UV radiation may exacerbate immune-mediated skin diseases. At noon on a sunny summer day the UVB exposure rate is typically $6-8 \mathrm{~J} / \mathrm{m}^{2}$ per $\mathrm{s}^{25)}$ therefore, the dose used in this study $\left(0.1-1 \mathrm{~kJ} / \mathrm{m}^{2}\right)$ represents only a few minutes of exposure. The epidermis may play an important role in the immune response because it is directly exposed to UVB. Therefore, we used human keratinocyte (HaCaT) cells to investigate of the effects of UVB on the production of inflammatory cytokines (IL-10 and TNF$\alpha$ ) and NO.

Consistent with previous reports, ${ }^{15,17,26-28)}$ UVB irradiation $\left(0.25 \mathrm{~kJ} / \mathrm{m}^{2}\right)$ significantly increased not only IL-10 and TNF- $\alpha$ production (Fig. 2), but also NO production (Fig. 3), by HaCaT cells. Decreases in IL-10, TNF- $\alpha$, and NO production seen at $1 \mathrm{~kJ} / \mathrm{m}^{2}$ may be due to cell death induced by such high doses of UVB irradiation. Several studies have shown that IL-10 is induced in human keratinocytes by UVB irradiation. ${ }^{15,27)}$ Nishigori et al. showed that unrepaired DNA damage activates the production of IL-10 in UVB-irradiated murine keratinocytes ${ }^{29)}$ and CurielLewandrowski et al. showed that IL-10 production by UVB-irradiated keratinocytes is increased by small DNA fragments, such as thymidine dinucleotides. ${ }^{30)}$ We also found that IL-10 induced NO 

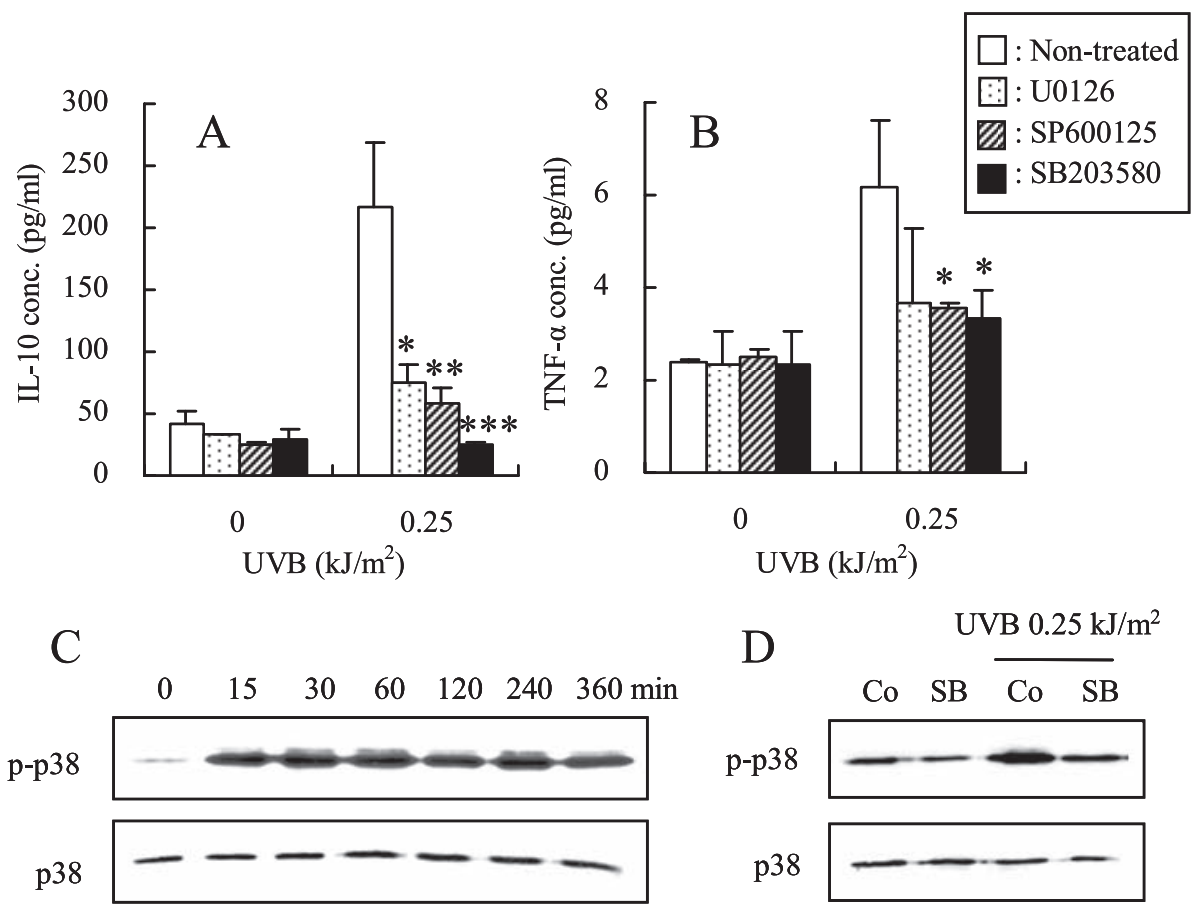

Fig. 6. Inhibition of UVB-induced Cytokine Production by MAPK Inhibitors

$\mathrm{HaCaT}$ cells were incubated for $1 \mathrm{hr}$ in 10\% FBS/DMEM with the ERK inhibitor, U0126 $(1 \mu \mathrm{M})$, the JNK inhibitor, SP600125 $(10 \mu \mathrm{M})$, or the p38 MAPK inhibitor, SB203580 $(10 \mu \mathrm{M})$. After UVB irradiation $\left(0.25 \mathrm{~kJ} / \mathrm{m}^{2}\right)$, cells were cultured in $10 \% \mathrm{FBS} / \mathrm{DMEM}$ for a further $24 \mathrm{hr}$. Each value represents the mean \pm S.D. of triplicate cultures. Significant differences from the UVB-irradiated group are indicated: ${ }^{*} p<0.05 ;{ }^{* *} p<0.01 ;{ }^{* * *} p<$ 0.005. (A) IL-10, (B) TNF- $\alpha$. (C) HaCaT cells were exposed to UVB $\left(0.25 \mathrm{~kJ} / \mathrm{m}^{2}\right)$ and cultured in $10 \%$ FBS/DMEM for $0,15,30,60,120,240$, or $360 \mathrm{~min}$ at $37^{\circ} \mathrm{C}$. At each time point, p38 MAPK activation was assessed by immunoblotting. (D) Cells were pretreated with the specific p38 MAPK inhibitor, SB203580 $(\mathrm{SB} ; 10 \mu \mathrm{M})$, for $60 \mathrm{~min}$, followed by irradiation with UVB $\left(0.25 \mathrm{~kJ} / \mathrm{m}^{2}\right)$ for $15 \mathrm{~min}$ at $37^{\circ} \mathrm{C}$. At each time point p38 MAPK activation was assessed by immunoblotting.

production (Fig. 5), suggesting a new role for IL10 in the exacerbation of immune diseases such as $\mathrm{AD}$ and asthma induced by solar UVB. The concentration of IL-10 added by this experiment was higher than that of IL-10 produced by UVB irradiation (Fig. 2A). Accordingly, it is suggested that not only IL-10 but also other signaling factor are related to the NO production by UVB irradiation. Further research into the role of IL-10 and NO production is now under way. NO donor increased the level of TNF- $\alpha$, but the concentration of TNF- $\alpha$ added by this experiment did not significantly increased NO production (Figs. 4B and 5).

The mechanism underlying the UVB-mediated increase in both IL-10 and TNF- $\alpha$ production, and the subsequent induction of NO production, was not known. Therefore, we focused our research on the signaling pathways involved in the production of these proinflammatory mediators. First, we investigated whether the MAPK signaling pathway is involved in the production of IL-10 and TNF triggered by exposure to UVB irradiation (Fig. 6A and 6B). We found that U0126, SP600125, and SB203580 (inhibitors of ERK, JNK, and p38 MAPK, respectively) specifically inhibited the production of IL-10 and TNF- $\alpha$. The results showed that the increase in IL-10 and TNF- $\alpha$ induced by UVB irradiation led to the activation of these kinases, which is in agreement with previous reports. ${ }^{31-33)}$ Da Silva et al. showed that UVB irradiation induced the increase of TNF- $\alpha$ and NO with p38 MAPK activation in the mouse astrocytes. ${ }^{31)}$ Caffeic acid significantly suppresses UVB-induced IL-10 mRNA expression in murine skin and it also inhibits the activation of $\mathrm{p} 38$ MAPK. ${ }^{32)}$ Song et al. showed that administration of the p38 MAPK inhibitor, SB203580, suppresses increased NO production, resulting in the release of IL-10 by murine macrophages. ${ }^{33)}$ These results correspond well with those of our study (Fig. 6A and 6B) and indicate that MAPK is the key regulator of IL-10 and TNF- $\alpha$ production. Additionally, we measured the UVB-induced phosphorylation of p38 MAPK (Fig. 6C and 6D). As shown in Fig. 6D, UVB-induced p38 MAPK activation was inhibited by SB203580 of p38 MAPK inhibitor. Thus the increased production of IL-10, TNF- $\alpha$, and NO in- 
duced by UVB may be the result of activation of the p38 MAPK signaling pathway.

In conclusion, it is suggested that sunlight may promote the development of dermatitis and other allergic diseases by augmenting inflammatory responses through the increased production of proinflammatory cytokines and NO. Previously, we investigated whether UVB irradiation could induce AD in mouse model. ${ }^{9)}$ The results showed that the development of dermatitis-like skin lesions and the increased production of IL-10, TNF- $\alpha$, and NO were promoted by exposure to UVB. ${ }^{9)}$ IL-10 is proallergic, and both TNF- $\alpha$ and NO promote inflammation. These mediators, produced in the epidermis, not only act locally but also affect the whole body, possibly resulting in the onset of immunemediated diseases. The results of this study constitute important findings in the epidemiologic study of the direct effects of UVB irradiation on human skin.

\section{REFERENCES}

1) Nole, G. and Johnson, A. W. (2004) An analysis of cumulative lifetime solar ultraviolet radiation exposure and the benefits of daily sun protection. Dermatol. Ther., 17, 57-62.

2) Kawanishi, S., Hiraku, Y. and Oikawa, S. (2001) Mechanism of guanine-specific DNA damage by oxidative stress and its roale in carcinogenesis and aging. Mutat. Res., 488, 65-76.

3) Kulms, D., Zeise, E., Poppelmann, B. and Schwarz, T. (2002) DNA damage, death receptor activation and reactive oxygen species contribute to ultraviolet radiation-induced apoptosis in an essential and independent way. Oncogene, 21, 5844-5851.

4) Kobayashi, S. (2006) UVB-induced skin damage and the protection/treatment-effects of a novel, hydrophilic gamma-tocopherol derivative. Yakugaku Zasshi, 126, 677-693.

5) Young, A. R., Chadwick, C. A., Harrison, G. I., Nikaido, O., Ramsden, J. and Potten, C. S. (1998) The similarity of action spectra for thymine dimers in human epidermis and erythema suggests that DNA is the chromophore for erythema. J. Invest. Dermatol., 111, 982-988.

6) Ichihashi, M., Ueda, M., Budiyanto, A., Bito, T., Oka, M., Fukunaga, M., Tsuru, K. and Horikawa, T. (2003) UV-induced skin damage. Toxicology, 189, 21-39.

7) Lo, H. L., Nakajima, S., Ma, L., Walter, B.,
Yasui, A., Ethell, D. W. and Owen, L. B. (2005) Differential biologic effects of CPD and 6-4PP UVinduced DNA damage on the induction of apoptosis and cell-cycle arrest. BMC Cancer, 5, 135-144.

8) Kripke, M. L., Cox, P. A., Alas, L. G., Yarosh, D. B. (1992) Pyrimidine dimers in DNA initiate systemic immunosuppression in UV-irradiated mice. Proc. Natl. Acad. Sci. USA., 89, 7516-7520.

9) Mutou, Y., Ibuki, Y. and Kojima, S. (2007) Immunomodulatory effects of ultraviolet $\mathrm{B}$ irradiation on atopic dermatitis in NC/Nga mice. Photodermatol. Photoimmunol. Photomed., 23, 135-144.

10) Hamilton, R. G. (2010) Clinical laboratory assessment of immediate-type hypersensitivity. J. Allergy Clin. Immunol., 125, 284-296.

11) Matsumoto, M., Ra, C., Kawamoto, K., Sato, H., Itakura, A., Sawada, J., Ushio, H., Suto, H., Mitsuishi, K., Hikasa, Y. and Matsuda, H. (1999) IgE hyperproduction through enhanced tyrosine phosphorylation of Janus kinase 3 in NC/Nga mice, a model for human atopic dermatitis. J. Immunol., 162, 1056-1063.

12) Gao, X. K., Nakamura, N., Fuseda, K., Tanaka, H., Inagaki, N. and Nagai, H. (2004) Establishment of allergic dermatitis in NC/Nga mice as a model for severe atopic dermatitis. Biol. Pharm. Bull., 27, 1376-1381.

13) Vestergaard, C., Yoneyama, H., Murai, M., Nakamura, K., Tamaki, K., Terashima, Y., Imai, T., Yoshie, O., Irimura, T., Mizutani, H. and Matsushima, K. (1999) Overproduction of Th2specific chemokines in $\mathrm{NC} / \mathrm{Nga}$ mice exhibiting atopic dermatitis-like lesions. J. Clin. Invest., 104, 1097-1105.

14) Asadullah, K., Sterry, W., Stephanek, K., Jasulaitis, D., Leupold, M., Audring, H., Volk, H. D. and Docke, W. D. (1998) IL-10 is a key cytokine in psoriasis. Proof of principle by IL-10 therapy: a new therapeutic approach. J. Clin. Invest., 101, 783-794.

15) Enk, C. D., Sredni, D., Blauvelt, A. and Katz, S. I. (1995) Induction of IL-10 gene expression in human keratinocytes by UVB exposure in vivo and in vitro. J. Immunol., 154, 4851-4856.

16) Yoshida, Y., Kang, K., Berger, M., Chen, G., Gilliam, A. C., Moser, A., Wu, L., Hammerberg, C. and Cooper, K. D. (1998) Monocyte induction of IL10 and down-regulation of IL-12 by iC $3 b$ deposited in ultraviolet-exposed human skin. J. Immunol., 161, 5873-5879.

17) Da Silva, J., Pierrat, B., Mary, J. L. and Lesslauer, W. (1997) Blockade of p38 mitogenactivated protein kinase pathway inhibits inducible nitric-oxide synthase expression in mouse astro- 
cytes. J. Biol. Chem., 272, 28373-28380.

18) Yamaoka, J., Sasaki, M. and Miyachi, Y. (2000) U1traviolet $\mathrm{B}$ radiation downregulates inducible nitric oxide synthase expression induced by interferongamma or tumor necrosis factor-alpha in murine keratinocyte Pam 212 cells. Arch. Dermatol. Res., 292, 312-319.

19) Tsukumo, Y., Andoh, T., Yamaguchi, T., Nojima, H. and Kuraishi, Y. (1999) Involvement of nitric oxide in itch-scratch response of NC mice. Yakurigaku Zasshi, 114, 17-21.

20) Taniuchi, S., Kojima, T., Hara, Mt. K., Yamamoto, A., Sasai, M., Takahashi, H. and Kobayashi, Y. (2001) Increased serum nitrate levels in infants with atopic dermatitis. Allergy, 56, 693-695.

21) Andoh, T. (2006) Importance of epidermal keratinocytes in itching. Yakugaku Zasshi, 126, 403408.

22) Cals-Grierson, M. M. and Ormerod, A. D. (2004) Nitric oxide function in the skin. Nitric Oxide, 10, 179-193.

23) Ding, W., Hudson, L. G., Sun, X., Feng, C. and Liu, K. J. (2008) As(III) inhibits ultraviolet radiation-induced cyclobutane pyrimidine dimer repair via generation of nitric oxide in human keratinocytes. Free Radic. Biol. Med., 45, 1065-1072.

24) Salojin, K. and Oravecz, T. (2007) Regulation of innate immunity by MAPK dual-specificity phosphatases: knockout models reveal new tricks of old genes. J. Leukoc. Biol., 81, 860-869.

25) Koponen, P. S. and Kukkonen, J. V. (2002) Effects of bisphenol $\mathrm{A}$ and artificial UVB radiation on the early development of Rana temporaria. J. Toxicol. Environ. Health. A, 65, 947-959.

26) Köck, A., Schwarz, T., Kirnbauer, R., Urbanski, A., Perry, P., Ansel, J. C. and Luger, T. A. (1990) Human keratinocytes are a source for tumor necrosis factor alpha: evidence for synthesis and release upon stimulation with endotoxin or ultraviolet light. J. Exp. Med., 172, 1609-1614.
27) Grandjean-Laquerriere, A., Gangloff, S. C., Le Naour, R., Trentesaux, C., Hornebeck, W. and Guenounou, M. (2002) Relative contribution of NF-kappaB and AP-1 in the modulation by curcumin and pyrrolidine dithiocarbamate of the UVB-induced cytokine expression by Keratinocyte. Cytokine, 18, 168-177.

28) Skiba, B., Neill, B. and Piva, T. J. (2005) Gene expression profiles of TNF-alpha, TACE, furin, ILlbeta and matrilysin in UVA- and UVB-irradiated HaCaT cells. Photodermatol. Photoimmunol. Photomed., 21, 173-182.

29) Nishigori, C., Yarosh, D. B., Ullrich, S. E., Vink, A. A., Bucana, C. D., Roza, L. and Kripke, M. L. (1996) Evidence that DNA damage triggers interleukin 10 cytokine production in UVirradiated murine keratinocytes. Proc. Natl. Acad. Sci. U.S.A., 93, 10354-10359.

30) Curiel-Lewandrowski, C., Venna, S. S., Eller, M. S., Cruikshank, W., Dougherty, I., Cruz, P. D., Jr. and Gilchrest, B. A. (2003) Inhibition of the elicitation phase of contact hypersensitivity by thymidine dinucleotides is in part mediated by increased expression of interleukin-10 in human keratinocytes. Exp. Dermatol., 12, 145-152.

31) Da Silva, J., Pierrat, B., Mary, J. L. and Lesslauer, W. (1997) Blockade of p38 mitogenactivated protein kinase pathway inhibits inducible nitric-oxide synthase expression in mouse astrocytes. J. Biol. Chem., 272, 28373-28380.

32) Staniforth, V., Chiu, L. T. and Yang, N. S. (2006) Caffeic acid suppresses UVB radiationinduced expression of interleukin-10 and activation of mitogen-activated protein kinases in mouse. Carcinogenesis, 27, 1803-1811.

33) Song, G. Y., Chung, C. S., Jarrar, D., Chaudry, I. H. and Ayala, A. (2001) Evolution of an immune suppressive macrophage phenotype as a product of P38 MAPK activation in polymicrobial sepsis. Shock, 15, 42-48. 